\title{
Reconciliation of Cultural Change and Economic Achievements of Descendants of Indian Indentured Labourers in Fiji
}

\author{
Dr. Suesh Kumar Pandey \\ Assistant Professor, School of Accounting and Law, College of Business Hospitality \& Tourism Studies, \\ Fiji National University, Nasinu Campus - Kings Road PO - 72222, Fiji Island
}

\begin{abstract}
The research paper aims at the indagation of the cultural changes for descendants of Indian indentured labourers in Fiji as comparison to Indians. It explores the aspects of living, traditional values, and workforce participation in both jurisdictions. It also enhances the different attributes of Indian culture en casting the cultural realm and the practices been reshaped in Fiji. The paper intends to systemically explain the differences between cultural and traditional characteristics of India's culture and Indo-Fijian culture. The inclination of lifestyle towards westernization and modernization will also be highlighted which amplifies the aspect of change to time and necessities. The research methodology adopted by the researchers is mixed-method and the data collection was made through the use of a questionnaire. Conclusively, the study done commutates the thorough use of questionnaires. Conclusively, the study done commutates the shift in cultural aspects and its reorientation and traditional values among Indo-Fijian living in Fiji.
\end{abstract}

Keywords - Culture Change; Indentured Labourers; Migration; Dowry; Caste System; Economic Achievements.

\section{Introduction}

Culture contributes towards the nurturing, progress and development of human life (Albert and Tromms dorf, 2014). It is a source of identity, norms, beliefs and values that surround people and their connection towards the community. Culture also defines the way human beings live with distinct spirituality and is a source of renewable power, i.e., if it is carefully nurtured, it will grow and flourish. When ignored, it is gradually lost or disappears (UNESDOC Digital Library, 2010). Culture thus refers to an environment organised by human beings which includes all the material and non-material goods that endure from one generation to the next (Kaur and Kaur, 2016). Material culture is about the physical aspects of life that are tangible such as food, household goods, clothing, jewellery, etc. Non-material culture includes ideas, thoughts, attitudes, beliefs and practices. Material and non-material structures of culture are interconnected and communicated through symbols as cultural beliefs (Kaur and Kaur, 2016).

Culture encompasses characteristics and knowledge of a particular group of people, their language, religion, customs, traditional knowledge, music and arts. According to the Center for Advanced Research on Language Acquisition (2019), (CARLA) University of Minnesota, culture means "shared patterns of behaviours and interactions of people, cognitive constructs and understanding that are learned by socialisation" (CARLA, 2019). Culture helps in the cognitive development of human beings, and their identity is nurtured by the social patterns unique to the group. Although culture is a complex issue, it principally includes a group's shared values, attitudes, beliefs, assumptions, artefacts, and behaviours, etc. In a broader sense, it incorporates faith, food, and lifestyle, dressing styles, marriage rituals, language, art and craft (Rössel and Otte, 2010). Through evolutionary approaches, one can experience the culture and transmission mechanisms to support changes in culture. Culture can contribute to societal change in the relevance of shift in psychology based on changes in ecological conditions (Michael and Grossmann, 2017). Culture plays a unique role in determining the migration patterns of people overtime. The migration choice and the impact of cultural proximity enables people to work outside the effects of preexisting culture and to maintain a positive change in cultural relationships for economic progress (Lanati and Venturini, 2018). Due to rapid sociological changes, even corporate entities are affected multi dimensionally and the corporate world is rapidly changing due to forces of moderation enhancing the competitiveness of business organisations. A study conducted by Dimitrova (2019) revealed that business organisations support the adaptation of change in the dynamic business environment which necessitates cooperation to implement the idea of change, represent the strategies, activities and policies for further development of the business.

According to Amartya Sen, culture is not "independent, unchanging and unchangeable" (Ginsurgh and Throsby, 2006, p.402). In a similar way, culture represents the way people do things around themselves. Culture does have that power which transforms an entire society on a large scale. It includes articulation, consistency in customs, upgrades values, norms and the behavioural aspects of individual. Culture allows the individual to synchronise their actions in a disciplined way that contributes to prosperity and progress (Celep et al., 2016). Furthermore, it represents far more than the way we do things around here (Martin, 2006) and is a critical strategy for large-scale change. 
Indenture became a worldwide phenomenon which was first initiated by the British as an experiment in Mauritius. The experiment was successful and it demonstrated to the world that the superiority of slave labour over 'free' labour persisted. The indenture system involved the mass migration of workers from India, China and South East Asia to labour-importing colonies. It was in 1833 when the British Empire led the emancipation of slaves to replace the liberated African labourers by Indian indentured labourers, but apprenticeship existed until it was finally abolished in 1938. Other European empires such as the French abolished slavery in 1848 while the Dutch was the last European power to abolish slavery on July 1, 1868 (An Overview of History of Indenture, n.d.). Though the system of indentured labourers was not so cherished, it continued in the colonies under the British Empire.

The beginning of Indian indenture started after the abolition of the slave trade to meet the demands of a labour shortage in the farming sector (The National Archives, n.d). The Fiji indenture system continued for 37 years starting from 4 March 1879 and was abolished in 1916. Within this period, 87 voyages were made carrying 60,965 Indian indentured labourers, and 60,553 reached Fiji to work (Girmit. Org.n.d). A large number of the labourers worked for the Australian Colonial Sugar Refining Company known then as the central hub of sugar plantations and the remaining workers were on copra and rice plantations, road construction and railway lines. This indentured system lasted for 37 years and, upon its abolition, people suffered inhuman conditions, were harshly punished for small mistakes, while children of five years old were forced to work with their parents and so on (Striking women.org. (n.d.)). The other factors that led to the misery of indentured labourers included illiteracy, lack of freedom, awareness and resources (Rai, 2016). After completion of work in the particular areas of their indenture tenure, 60per cent of these workers chose to settle in Fiji (Naidu, 2017). The experiences of the Indenture period (Girmit) formeda horrible nightmare associated with great adversity and suffering, leaving people withtears in their eyes and broken bodies; however, they managed to maintain their identities while creating associations beyond caste and religion (Zakia et al., 2016).

\section{Literature Review}

Culture as a subject of study determines the central behaviour of humans and has been noticed significantly as a major influencing factor in the day-to-day life of a person. It consists of the environment created by human beings and, principally, it determines the course of an individual's life (Herskovits, 1969). Furthermore, it has a strong connection with social networking practices, values, norms and development of the intangible heritage in several aspects of life (Chen, 2017). Culture functions at various stages of a life and a society alike, and involves lifestyle, dress, language, food, occupation, organisations, corporations, industry, nation, etc. (Groeschl and Doherty, 2000); nevertheless even corporate culture has not been left untouched by sociological culture which has a significant role at "various level[s] in international business management: marketing, human resource management, negotiation, product development, leadership among others" (Ooi, 2007, p.112). In another study, by Pathak and Pandey (2013), it was concluded that the impact of the culture of individuals can be understood by their behaviours and attitudes. While studying the work attitudes and behaviour of Indian and European employees, it was revealed significant difference between two groups of employees on certain measures like sensitivity to hierarchy, attitude, an inclination to working in groups, work pressure and punctuality (Pathak and Pandey, 2013).

Culture, an independent variable is used by many researchers to prove its effect on various dependent variables, for instance, economic growth (Johnson and Lenartowicz,1998), entrepreneurial and worldwide competitiveness (Lee and Peterson, 2000), product dispersal (Dwyer et al., 2005), reward management (Chiang, 2005), and leadership (Singh and Krishnan, 2007). Khanna and Karandikar (2013) found that collectivistic culture on the Indian buyers and the role of parents and spouse to maintain the culture of desire buying of Indian society with respect to consumerism. Similarly, cultural values have been seen in the tourism industry to pay special attention to the customer to enhance sales. Cultural differences within the country hold many subcultures which are hard to measure (Singh, 2007). A cultural assessment is necessary in every aspect of life despite of obstacles and to strengthen the strengths in communities (Munday, 2018).

A study conducted by Sotomayor et al. (2019), 'Tradition and modernity side-by-side: experiential tourism among Quechua communities', established that it is significant to exchange the cohabitation of modernity and traditions in experiential tourism which has a positive influence in heritage protection. Heritage protection is to protect the cultural values of a specified society. Pandey and Srivastava (2013) also exposed that a robust link exists between the Indian domestic tourist intention to purchase while using the experience at the store using artefact nonverbal interaction and strong communication with a salesperson at the store besides demographic variables. They further advise managers in the tourism field to be alert and vigilant to macro communication and being aware of the Indian domestic tourists' attitude to purchase in order to uplift their industry. The prosperity of culture, and cultural citizenship as cultural policy in the growth of socio-economic culture in tourism is based on area 
difference in a same province. It depends on cultural uniqueness to gain tourism profit at the customer satisfaction and expense of service, and an approach to develop a multicultural identity for protecting the culture in contemporary society (Qu et al., 2019).

Cultural change is global political culture changes has no exception. Political culture helps to form the political process and that reflects new transforms in that process. A study by Collect and Dalton (2017) defined that the culture is not only clarified for short-term, but it also have a broader influence on governments and politicians. In some Asian nations, people like political reforms with leading movements and their support of eventual reforms. Similarly, in other Asian countries, cultural changes appear is to move beyond the community's choice. In both cases, a stronger connection is there between the administration and the public. The concept of cultural change has been expressed by Zhang and Weng (2017) where not all cultural values are equal in the context of developing individualism to harmonize with ongoing collectivism. The pattern of change in Chinese culture is due to the current departure from collectivism to individualism based on attitude and social trends in the communities.

\section{Socio-economic Challenges Influencing Cultural Change: A Conceptual Framework}

In general, cultural change is conceived of as a process which incorporates the external and internal relationships of social dimensions, long-term promotional value and disciplined actions that contribute to progress (Bhagonandam and Rao, 2015). Singh (2010) identified that the cultural values play an important role in understanding the societal morals and the behaviour of the decision makers in the workplace for the success of international organizations in India. He considered contemporary aspects of cultural change and economic achievements of Indian-descendant labourers in Fiji. It provides descriptive pieces of information and the factors that influence to achieve a new pathway in the life of descendants of indentured labourers. From the earlier studies, it is clear that: cultural value, caste, education, family background, social networks, value and belief may influence change in their culture. From the above discussion, it is obvious that there is a need to build a conceptual framework for linking the socio-economic challenges that influence cultural change. The researchers make a modest effort to design a framework of socioeconomic challenges and its environmental factors that influence cultural change.

In the figure, the signs indicate that there is a strong connection between cultural and socio-economic environment and cultural change. In the broad sense of cultural environment, it is more about 'way of life', values, belief, traditions, customs and behaviours which define the relationship between individuals and communities:"the set of values, norms or benchmarks that define the state of social relations, shared goals, cooperative behaviour and reciprocity among individuals and communities within a given society" (OECD, 2005, p.27). In this study, most of the factors have a positive relationship with cultural change except the caste system in the cultural dimensions. Previous research is indicated with a positive sign based on individuals' professions those who are keen to continue their business based on the caste system (Bhagonandam and Rao, 2015). The Indian indentured labourers have lost their caste during the Girmit system for reasons of survival but it assists them to adopt western culture for reasons of economic prosperity.

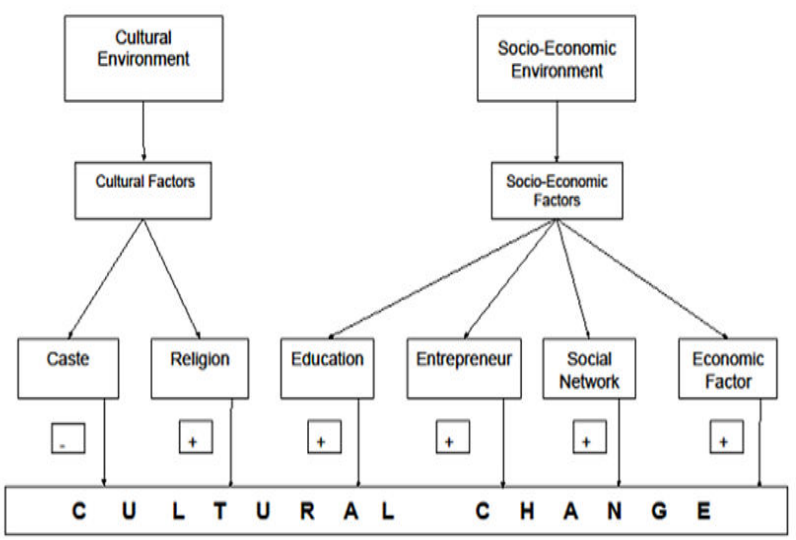

Fig.1: Conceptual framework

Source: Conceptual framework proposed by authors

According to Max Weber's theory (1930), religious and social affiliations are essential for the economic progress of any country. His theory suggest that some religions are more conducive than others to entrepreneurship. However, religion is designated with a positive sign that shows indentured labourers still stick with their religions and their prayer systems in their daily life. Resource-Based View theory is more about the factors related to the strength and weakness of entrepreneurs, firms, network, orientation and resources (Madhani, 2010). Through education, indentured labourers grasped the opportunities to learn, sustain them and became self-reliant in the community. The institutional theory places much significance on developing entrepreneurs' work and taking care of business. With this theory, it is asserted that there is a positive relationship with cultural change (David et al., 2017). Social networking theory says that there is a positive relationship with enhancing social networking of individuals and it is easy to adopt the system in the change of culture of individuals. Finally, the economic factor has a wider role to promote the progress of people in any society 
and it indicates a positive relation to meet the demand of the individuals in shaping the culture of the people (Bhagonandam and Rao, 2015).

\section{Research Objectives}

The objective of this study is to explore the cultural change of descendants of Indian indentured labourers in Fiji and compared with Indians in India from where their ancestors originally came. The interconnected roots of descendants of Indian indentured labourers motivated the researchers to examine the caste-based division of work, loss of language, the standard of living, workforce participation and other attributes of Indian culture in Fiji. Furthermore, researchers analysed the adaptation to western culture, enhancing educational progress and economic achievements in their day-to-day life in order to accomplish this study.

\section{Methodology}

This paper employs qualitative and quantitative methods for the validity of the research which draws on three sources of information: (1) secondary sources of information and documents published on indentured labourers; (2) unstructured interviews conducted with free Indo-Fijians after the end of the indenture system and Indians in India of concerning states; and (3) analysis of the interviews with indentured labourers, lived experiences, and observations. In addition to this, the principal researcher is from India, has been working for the last six years in Fiji and has first-hand knowledge of both cultures. Furthermore, one of the co-researchers was born in Fiji and has in-depth experience and knowledge of Indo-Fijian culture. The survey was conducted on a close-ended questionnaire, which consisted of sixteen questions distributed to participants in Viti Levu and Vanua Levu in Fiji, and the participants from the northern part of India, since it is believed that most of the indentured labourers came from that part of India which presently consists of places such the Purvanchal belt of Uttar Pradesh, Bihar and Madras (at present Chennai) (Misir, 2016; Naidu, 2017).

The questionnaire was randomly distributed, and a total number of 448 participants responded. The structure of the questionnaire was such that it touched on the primary institutions of the society.Participants put forward their opinions about the type of marriage, dowry system, the caste system in India, their profession, reservation in jobs, way of living and dressing, language, etc. This study tried to get views of Indians living in India and indentured labourers living in Fiji about certain basic customs and the practices of Indian culture. The most important aspect of the research was to find out whether the indentured labourers have adopted western culture while keeping their roots alive with regard to Indian culture. The questionnaire further explored the main reason as to why descendants of Indian ancestors had travelled so far, whether they were compelled or came voluntarily or if they were in search of a better life which encouraged them to travel to Fiji.

The researchers would not have been able to conclude the findings without the empirical examination of the indentured labourers in Fijialong with the Indians living in states of Uttar Pradesh, Bihar, West Bengal, etc. (Girmit.org, n.d.). It is believed that most of the indentured labourer's descendants had come from these states. Before getting into the sampling structure, it is important to know the limitation of the sample size. India is a vast country both in territorial aspects and population size. It is also pertinent information (from the Fiji Hindi) that the Indian descendants who came to Fiji for sugar plantation work came from these mentioned states. Although they may have come from these locations in India, it is an impossible task to obtain the views of the entire population of immigrants from these states.

\section{Results and Interpretation}

The preliminary investigation was regarding the educational qualification of the participants. The figure shows the educational qualifications of the participants; these were divided into age groups of 30 to 40 years, 41 to 50 years and 51 and above. Finding out the educational qualification was essential to conclude the acceptance of cultural values by the participants.However, the researchers wanted to obtain the views of educated people because they wanted to review the opinions of contemporary Indian society. These states of India are highly populated (Statistics Times, 2019), and it was not possible for the researchers to contact the people who are related to indentured labourers that came to Fiji. The sample size for Indians from the northern part of India was limited to 244 participants.

\section{Figure 2 Age and Educational Qualification of Indians in India}

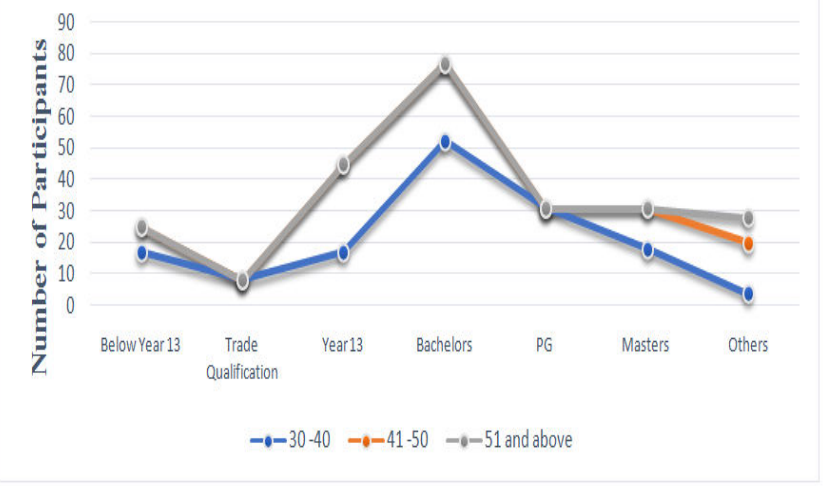

Fig.2: Age and Education qualification in India

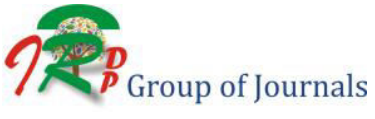


Figure 2 demonstrates the age group and educational qualifications of the participants from Northern India. It is explicit in the chart that participants from the age group between 30-40 years have attained higher educational qualifications in terms of Bachelors, Postgraduate and Masters Degrees. Indeed, this gives us a fair idea that the young population are more focused on higher education as compared to the time of the colonial period. This also reflects that the young generation is moving away from traditional farming to contemporary job sectors. This is clear from the fact that the rate of immigration from villages to cities has increased drastically in the last few decades (http: // censusindia. gov.in / Census_And_You / migrations .aspx). This immigration has overloaded cities like Mumbai, New Delhi, Kolkata and other big cities in India.

When it comes to the descendants of indentured labourers of India the sample size was 204 participants, and the rationale for selecting these participants is to find out receptiveness of Indian culture by the descendants of indentured labourers living in Fiji.

\section{Figure 3 Age and Education Qualification of Indians in Fiji}

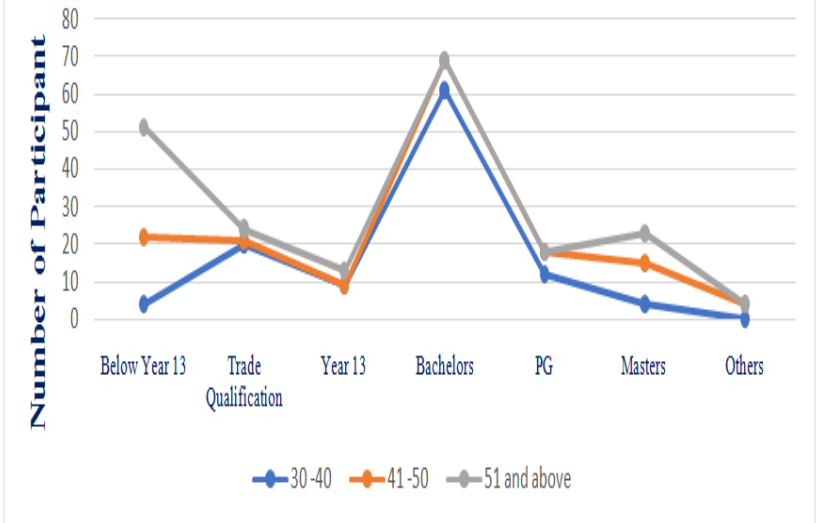

Fig.3: Age and Education qualification in Fiji

Figure 3 demonstrates the age group and educational qualifications of the Indo-Fijian participants from Fiji. It shows that the age group between30-40 is more focused on achieving higher qualification such as Bachelors and Postgraduate qualifications. The participants from the age group 40-50 have achieved higher qualifications like Masters Degrees and above because these qualifications were pioneered later in Fiji. This also clearly reflects that the young generation does not want to continue the legacy of sugarcane farming by indentured labourers. Indians were transported to Fiji by the British government for sugarcane plantation work; however, once the British left Fiji, the majority of the Indians decided to stay back in Fiji. Nevertheless, as time has passed, the great-grandchildren of indentured labourers started focusing on education for making them competitive in the job market. It is clearly evident that Indo-Fijians are playing a vital role in the economic development of Fijiand this has led the IndoFijians to prosper and contribute towards the development of the Fijian economy.

\subsection{Cultural Change of Indentured Labourers in Fiji}

The process of cultural change appears when the transformation in the pattern of the culture isdue to both internal and external factors. Cultural change happens mostly due to a change of place or country, contact with other culture, developments and internal adjustment of society (Shodhganga, n.d.). There are various reasons for interaction between different communities and distant cultures through trade, exploration, multinational business, globalisation, etc. Through observation, it has been noticed that this perception changes when a new culture is adopted due to loss of traditional knowledge, thoughts and beliefs. As time passes, the practice leading to cultural change appears as a consequence of diffusion, acculturation and transculturation through contact between societies. Many of us are aware that 'times have changed', particularly when we compare our lifestyles to the lifestyles of the previous generation. Some dramatic changes have occurred due to changes in technology, changes in the roles of women and changes in attitude about inter-personal relationships and marriage. But it is true that such changes are not uncommon nor did they happen overnight. (Ghimire and Samuels, 2014).

In contemporary society, the lifestyles of the descendants have drastically changed due to education and economic prosperity. J.R Pearson, the Secretary of Indian Affairs in Fiji (1932), wrote, "It is [of] great importance that the local Indian should learn that they are 'Fijians' first and only incidentally Indian by origin and should cooperate with other sections and the administration in working out their common destiny" (Naidu, 2017). Fiji has been multi-ethnic and multi-cultural society since the midnineteenth century with its distinctive cultural, linguistic and religious attributes (Naidu, 2013).There are many examples of Fijian culture, and one of the essential practices in that culture is the drinking of Kava. However, the practice of drinking Kava had been adopted by indentured labourers from the indigenous people. Yaqona (Kava)is genuinely the national drink of Fiji, which is an essential phenomenon in Fijian culture. No ceremony can take place without yaqona being drunk, and it is seldom absent even in casual meetings and discussions, and the acceptance of Kava is increasing day by day amongst IndoFijians. Kava (piper methysticum) is known as the national beverage consumed by men but also some women of all ethnicities (Mohanty, 2017). 


\subsection{Migration of Indentured Labourers from India}

It would not be possible to comprehend the change of culture of Indo-Fijians who arrived from India without finding out the reasons for their emigration. The research concentrates only on Indo-Fijians whose ancestors came from India as indentured labourers. And they were asked to respond within four options, firstly: voluntarily left home; secondly as a result of false promises; thirdly because of hardship; and lastly, in search of a better job.

\section{Figure 4 Impetus for Migration of Indentured Labors}

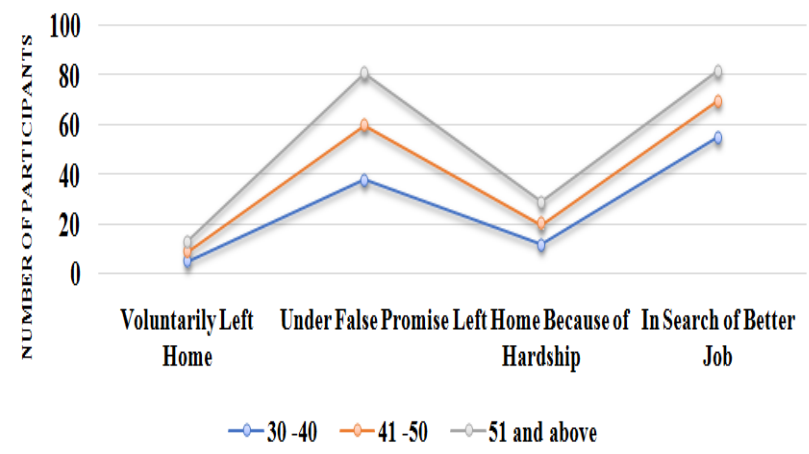

Fig.4: Impetus for Migration of Indentured Labours

As the Figure demonstrates, the participants in the age group of 30 to 40 years stated that their ancestors migrated to Fiji in search of a better job. However, the young generation was not accurate as to why they thought Indians came to Fiji as, between 1879 to 1916 Indians were brought to Fiji as indentured labourers to work on the sugar plantations (Gillion, 1958) and these indentured labourers are also known as Girmityas. The participants from the age group 30-40 also believed that their ancestors were brought to Fiji to work on sugar plantations under false pretences. If we look towards the participants above 50 years, they responded differently, and many of them believed that their ancestors came to Fiji because of false promises made to them.

The study also illuminates the reasons as to why Girmityas stayed behind in Fiji when the British Government had given them free passage for returning to India. Majority of the participants stated that there must be some other reason as to why they remained in Fiji. There were four options in the questionnaire to answer: 'Why didn't they go back when the British government was giving free passage to them?' These options were: first, had they run away from home? Second, did they tell their family before leaving home? Third, were they afraid of not being reaccepted in their society; and lastly, any other reasons? The inference which can be drawn from this research is that the majority of the participants who were from the age group 30-40 do not have any specific information as to why Girmityas stayed behind in Fiji. Out of all the participants, $5.90 \%$ answered the first option; $9.80 \%$ replied in favour of the second option; $19.11 \%$ supported the third option; and $65.19 \%$ went for the last option.

\subsection{Loss and Change of Language}

The majority of the indentured labourers came from the northern part of India, and they were well versed in the Awadhi language which is spoken in Uttar Pradesh - which has a significant influence of Bhojpuri as well as the Bihari language (Naidu, 2017). During the time of recruitment from India, the labourers were compelled to live and eat together at the holding depots in Calcutta and Madras (Lal, 2000). Even though they had their languages, these indentured labourers were forced to compromise their languages when they were shipped together and had to live together as a part of Jahaji Bhai/Bhaini in Fiji. It was the new environment that compelled them to lose and change their languages.

Bhojpuri and other languages were popular and later became Fiji Hindi. The descendants were forced to adopt western culture and use English as their first language in their daily lives, and that helped them in the future. It has been observed that there was considerable loss of original languages.

\subsection{Clothing and Costume}

Clothing and costume identify the culture of a particular individual. Indian clothing and costumes vary widely due to diversity in the country. The influence of traditional clothing is based on local culture within rural and urban settings. There are many styles of dress, like sari (Kalman, 2009) and wrapped garments, Lehenga Choli, Churidaar and Salwaar Kameez for women and KurtaPyjama, Dhoti, Panche or Lungi, Sherwani for men. From the last 138 years in Fiji, the clothing and customs of IndioFijians have changed due to the influence of western culture in urban areas. The descendants of indentured labourers adopted western clothing so that they could easily blend into the Fijian culture; however, they have kept their traditional clothing use alive especially on special occasions.

\subsection{Family Structure and Marriage}

The composition of the joint family includes all the members of the family like, parents, children, and in-laws and their offspring living together. Indian culture traditionally has a strong family bonding system which is based on an extended family system that includes every religion. For example, the extended family system in

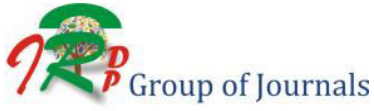


Hindus is known as Hindu Undivided Family and it is managed by the head of the family member recognised as Kartawho overlooks the day-to-day affairs, protection of joint property and holds the decision making authority (Suraj Bunsi Koer v. Sheo Prasad, 1880). From1911 to 1951, Indian household sizes remained intact (Bharadwaj, 2018). After that, with the economic progress and urbanisation, India has witnessed a break-up of the joint family system into nuclear families (Micklin, 1966) which is also prevalent in Fiji amongst the descendants of Indian indentured labourers. Many of these indentured labourers started their families when they chose to live in Fiji because most of them were below the age of 26 years (Misir, 2016).

With respect to marriage, researchers analysed the concept of marriage and its different attributes. Marriage is an institution between two families which has its own attributes. "Marriage is treated as an alliance between two families rather than a union between two individuals" (Prakasa,1982). Historically, arranged marriages have been noticeable in many cultures in different parts of India, and this tradition has weakened considerably during the 20th century. Traditionally in arranged marriages, the bride and groom were selected by older members in the family other than the couple themselves (Flanigan, 2000).Even in the modernisation era, most Indian marriages are planned by the parents and other respected family members (Sonawat, 2001). It has been a tradition in India that most of the marriages are arranged by some close family friends or relatives who play an integral part in arranging marriages.

Before the implementation of the Hindu Marriage Act, 1955 marriage was considered to be a sacrament (Muthusami v. Muthusami, 33 Mad 342; Bhagwati Saran Singh v. Parmeshwari Nandar Singh, (1944) ILR All 518) instead of a contract for procreation. It was believed that in performing religious rituals (Section 7 of the Hindu Marriage Act, 1955), a person to be married. However, in the majority of Indian weddings, the bridegroom accepts a dowry provided by the bride's family. Dowry also includes valuable items like household goods, jewellery and a certain amount of cash depending upon the size of marriages that the bride could manage in her lifetime (Heitzman, 2012)

\subsection{Culture of Dowry}

India, being one of the oldest civilisations, with the time, developed many evil traditions, and one of them is dowry. Even in modern society, the menace of dowry is prevalent. According to the Cambridge dictionary, dowry is a sum of money or property which is given by the bride's family to the bridegroom and his family member (Cambridge Dictionary, 2019). Dowry became the important issue during the 1970s because of the drastically growing deaths of young brides (Palriwala, 1989). The evil of dowry was shame to India on many occasions. Some of the western jurists have remark marriage as a market, and that deteriorating the women (Edlund, 2006).

In the late $80 \mathrm{~s}$, there has been a debate about whether dowry is the share of the daughter in her parent's property as an inherent right or it is the price paid by bride's parents for marriage (Jain, 1989). May as it may be, dowry in common parlance is understood as a payment towards marriage, and it is a significant contributor to domestic violence (Kishwar, 1989). To curtail the menace of dowry, the Government of India in 1961 passed legislation known as the Dowry Prohibition Act, 1961. This part of legislation considered the acceptance and offering of dowry is an offence and which attracts the 5 years imprisonment with fine or both (Sec 3 of Dowry Prohibition Act, 1961). It is observed that dowry system is still very common in Indian society (Dalmia and Lawrence, 2005). However, many times the Apex Court of India has perceived the misuse of Anti-Dowry Laws (Sushil Kumar Sharma v. Union of India and others JT 2005(6)).

The study would not have been accomplished without knowing the views of the people about the dowry system that is still prevalent in the contemporary society of India. The Figure below shows the views of the Indians concerning dowry custom.

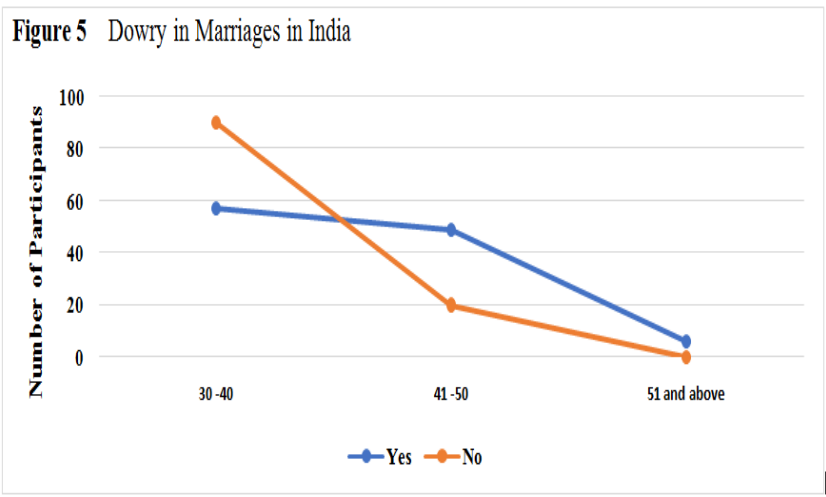

Fig.5: Dowry in Marriages in India

While seeking the views of the participants relating to accepting or offering a dowry, the majority of respondents from the age group of 30-40 years denied this; however, if the entire population of the participants are considered then the majority of them agreed that they have either accepted or given a dowry. Figure 4 shows that the majority of Indians still believe in the tradition of dowry, even those who have denied may have denied because of the fear of the Dowry Prohibition Act, 1961 or it might be due to a change in the mindset of the younger generation. As the figure denotes that participants above the age of 51 have 
accepted dowry, the culture of dowry was persistent. Even today it is a predominant tradition in most parts of India, specifically the northern belt of the Hindi speaking community as compared to the southern and eastern parts of India. Though there are stringent laws to prevent the dowry tradition in India, to some extent these have failed as well as, in Arnesh Kumar v. State of Bihar, the Apex Court of India showed its concern about the abuse of the dowry prohibition law and of Section 498A of Indian Penal Code, 1860. Figure 6 shows the views of the Indo-Fijian community with respect to the dowry custom.

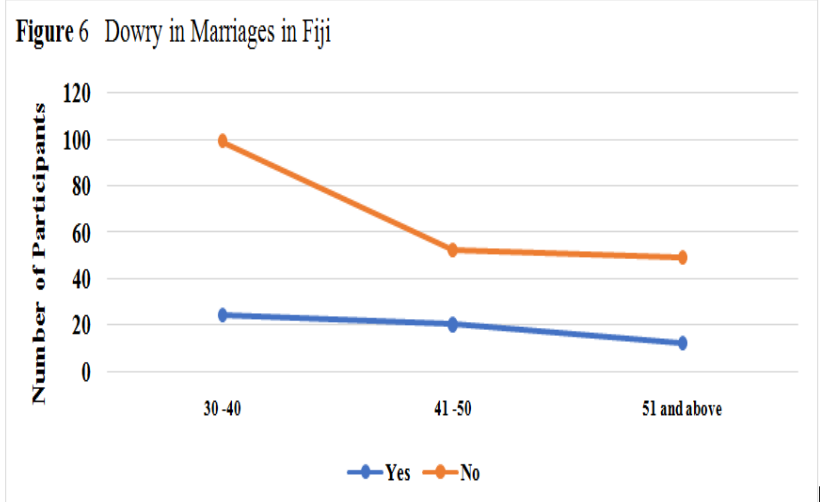

Fig.6: Dowry in Marriages in Fiji

The Indo-Fijian community, by and large, is not very much receptive towards the dowry system. As the figure indicates, the younger population (between 30-40 years) either have not taken dowry or are not willing to take dowry as compared to other age group participants.

Previously, arranged marriage was accepted by the Indo-Fijian community with its gift-giving culture to the bridegroom's family but, with time, this has changed, and there are more love marriages than arranged marriages. In India, inter-caste marriages are increasing, but the ratio is minimal as compared to Fiji. Amongst Indo-Fijians, intercaste and interracial marriages are accepted by society. It helps their parents to be free from the burden of the dowry system and leads the new generation to follow western culture in their lives. Due to this absence of dowry in marriages, Indo-Fijian society has overcome this menace.

\subsection{Caste-based Division of Work}

India's social structure implicates caste and the nature of work: people are supposed to work according to their caste; that may be in households, society or community and the world of work (Nayyar, 2011). The Indian Constitution highly praised the affirmative action and discriminatory justice, and also has included the caste-based reservation for bringing up the lower caste into the common stream of society (Bagde et al., 2016). The caste based reservation in jobs is based on two vital components: firstly, affirmative action in favour of so-called lower castes such as scheduled castes (SCs) and scheduled tribes (STs) and secondly proportional reserved seats for these groups in government jobs and higher educational institutions. Initially it was $15 \%$ for SCs and $7.5 \%$ for STs in 1950 when the Constitution was adopted (Nayyar, 2011). The Constitution of India part XVI empowers the government to reserve government jobs (Art. 15(4) and Art 16(4) of Constitution of India). Further, the Constitution $77^{\text {th }}$ Amendment Act, 1995 inserted new clause 4A in Art. 16, enables the government to provide reservation in promotion. The reservation does not only apply in government jobs and higher educational institute it also applies in Parliament, State Legislative Assemblies, Panchayats, and municipalities (Art 330, 242D, 233T of Constitution of India, 1950).

The reservation policy was revised from time to time, and Other Backward Classes were included in 1991 (Annual Report of National Commission for Backward Classes, 2013-14). In 1978 the President, exercising power under Article 340 of Constitution of India appointed a backward class commission, chaired by B.P. Mandal. The commission recommended $27 \%$ of reservation in favour of backward classes (Drishti, 2019). At present, the reservation in direct recruitment for government jobs is $7.5 \%$ for STs, $15 \%$ for SCs and $27 \%$ for other backward classes (Government of India, Ministry of Personnel, P.G., \& Pensions, Department of Personnel \& Training, Official Memorandum, 2010). In the Indra Sawhney case, the Apex Court of India upheld the $27 \%$ reservation for other backward classes, and restricts the reservation in total thatit should not exceed $50 \%$ of the total number of posts (Indra Sawhney v. Union of India, 1992, 1992 Supp 2 SCR 454, para 18).

In the case of Fiji, there is no such reservation system either in education or employment opportunities in government jobs. The descendants of Girmitiyas chose a principle of equal opportunities to every individual in the society, which helps them to lead their life on the basis of merit. However, the Girmitiyas lost their caste system during the struggle for survival, and their descendants developed a determination not to follow the caste-based divisions of work. They are getting their jobs based on their ability, knowledge and work experience without any discrimination based on caste, creed and culture. It has been a unique feature in the Constitution of India that has laboured in an immense effort to uplift socially deprived classes. Historically, it has been believed that the people belonging to lower castes such as cleaners, sweepers or grounds men were mistreated. And it was unfortunate that the people belonging to the upper castes maltreated the socially deprived castes. However, there has been a tremendous change in the perseverance of the upper class concerning the attitude towards the lower caste. 


\section{Achievements of Indian Indentured Labourers in Fiji}

One of the most important aspects of a culture is the attachment of people to their religion. The religious aspects in India are based on four major religions: Hinduism, Islam, Christianity and Sikhism (Office of the Registrar General \& Census Commissioner, India, 2001). The Hindu descendants of Indian indentured labourers have full faith in Hindu philosophies as karma and reincarnation (Rosen, 2019). Girmitiyas, and the offspring of Girmitiyas, developed the unique cultural, linguistic and religious attachment that prevails today (Rai, 2016). They put their hearts and souls during the struggle-filled days of the colonial period into nurturing their children so that their children would prosper. They built places of worship, organised religious and cultural events that everyone, irrespective of religion, caste, social and regional backgrounds attended. In a short time, they built a cohesive Indian community, most of their children thrived, not only as competent farmers, but also in numerous other occupations.

According to the Refugee Review Tribunal Australia, 2009, sources indicate that indigenous Fijians and IndoFijians comprise into relatively separate communities. But that longstanding tension between the communities has at times resulted in inter-communal violence. Reports indicate that race-based prejudice has been pervasive in Fiji, with native Fijians having received preference. However, in 2006, the interim government has shown intentions to reform a 'non-racial' nation.

Fiji has suffered from four coups (Fraenkel, 2007) which forced several descendants to leave Fiji and shift on neighbouring countries. The second migration gave them opportunities to start new lives which helped them to create a Pacific identity (Graf, 2014). The descendants of Girmitiyas preserved their religion and integrity. They still celebrate Hindu festivals such as Holi, Diwali, Ram Navami, Dussehra, Eid, etc., and follow their religion by reading Ramayana, Gita, Kuran and Guru Granth Sahib in their daily lives (Eck, 2002).

Indo-Fijians have played a vital role in the progress of learning centres throughout the country. The descendants of Girmitiy as made great efforts to create learning opportunities by establishing schools, colleges and universities. In spite of having a different religious background, they mainly focused on education and currently own and manage the schools and educational institutions.

The history of the schools for Indians began at the end of the 19th century in Fiji. The numerous educational institutions, namely the Arya Pratinidhi Sabha of Fiji, Sanatan Dharam Sabha of Fiji, and the Fiji Muslim League, opened various schools, colleges and a university. In 1898, the Methodist Mission and the Marist Brothers started the first formal school for the Indians (Moag, 1978).The involvement of Indian associations in education motivated the beginning of a self-created demand for education for descendants of labourers to help them in later decades. The Arya Pratinidhi Sabha of Fiji, managed and operated by Arya Samaj, was the first Indian organisation to lay the foundation of a school (in 1916) at Sawani, Lautoka, and the same became functional in 1918 under the name of Gurukul Primary School, for Fiji Indians (Arya Samaj in Fiji, 2012).

The Sabha worked actively for the development of educational institutions and constructed Pandit Vishnu Deo Memorial College in 1972 and,in 2005,they built the University of Fiji at the same site as GuruKul Primary School. At present, Sabha also owns and manages 14 preschools, 18 primary schools, seven secondary schools and one each of commercial, religious, social services as well as a higher education centre (Arya Samaj in Fiji, 2012). People educated in these schools are contributing to all aspects of life.

\subsection{Role of Men and Women}

Till this century, women were expected to take the role of a wife and mother, taking care of the children and working for the family's well-being. They were engaged mostly in cooking food, meal quality, processing, preserving and storage of grains, etc. (Biswas, 2016). Men were the sole breadwinners and protectors of the family. Today, there is no doubt that the roles of men and women have drastically changed. This change mostly occurred because of the girl's education and the supportive attitudes of their parents. However, women were, to a great extent, kept out of the working environment due to the restrictions imposed and social stigma. Nowadays, girls are permitted to attend educational institutes and achieve excellence there. Our modern society has opened the thoughts of men to allow women to develop their identities, and play a leadership role in their families as well as in other aspects of life, as enunciated by Madsen in her research brief entitled: "Why do we need more women in leadership of higher education?" (Madsen, 2015).

The participation of women is not only limited to developing their identities and involvement in leadership roles but also to construct a work life balance and manage themselves to fit in the family structure. A study conducted in the USA by Meyerson (2001), revealed that many women managers found themselves more at risk of stress"due to multiple role demands", which are "inherent 
when running a career" while taking care of their home. A similar study investigated by Delina and Raya (2016, p.5), argued that "the boundaries and roles within the workplace have been blurred", thus proposing that there should not be gender-based roles, responsibility and accountability in workplaces in the contemporary society. At present, there is no uncertainty that the roles of men and women have drastically changed and women have developed multiple roles while maintaining a work-life balance to fulfil family responsibilities.

The idea of women's empowerment motivates the community to come forward and raise the status of women through providing opportunities for education, raising awareness, literacy and encouraging women to make lifedetermining decisions in dealing with the various problems in society. A similar conclusion was revealed by Sondhi and Chawla (2014) in their study, "A cluster analysis approach to grouping Indian women professionals", that women's education in India has improved over the past few decades, and their participation in employment has increased in many professions, but that they remain underrepresented in leadership positions. However, some Indian states retain the concept of 'maternal' society such as the state of West Bengal, Gujrat, Kerela, and some of the states of North-East India. In respect to Indo-Fijian society in Fiji, this provides a different perspective - where women are working shoulder to shoulder with men. This provides women with ample opportunities to perform leadership roles in different aspects of society.

After Independence, Fiji has made a lot of changes and have re-adopted their inherited cultural customs. The women have equal participation in the economic progress of the country. According to the World Bank, IBRD.IDA (International Labour Organization, ILOSTAT database estimate, 2019) estimates $24 \%$ of the female population aged 15 plus of India are involved in the labour force as compared to Fiji where there is a much higher engagement of female labour force $(38 \%)$. It shows that the female labour force participation has increased by $58 \%$ in the case of the Fijian economy as compared to India, which ultimately helps the economic growth of the country. In Fiji, there are no social barriers or restrictions for working women which allows them to lead an affordable life. In the Indo-Fijian community, there are more working hands to support the family. To establish this proposition, the researchers collected statistics on how many people are working in a house for comparative analysis.

\subsection{Number of Persons Working in a Family}

The objective of this section is to find out the number of persons contributing to the family household income. Traditionally, India has been considered to be a male- dominant society; however, in contemporary Indian society, there has been an increase in the number of females contributing towards the household income (see Figure 7). The objective behind this section of the research is to make a comparative analysis between the female contribution to household income as well as the number of people contributing to this income in India and Fiji._Figure 7 describes the position of Indians while figure 8 demonstrates the position of Indo-Fijians in Fiji.

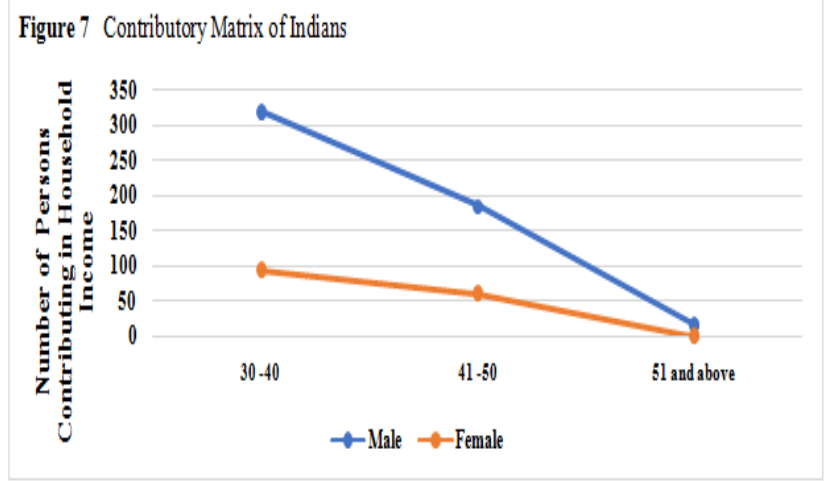

Fig.7: Contributory Matrix of Indians

Figure \& Contributory Metrix of Fiji

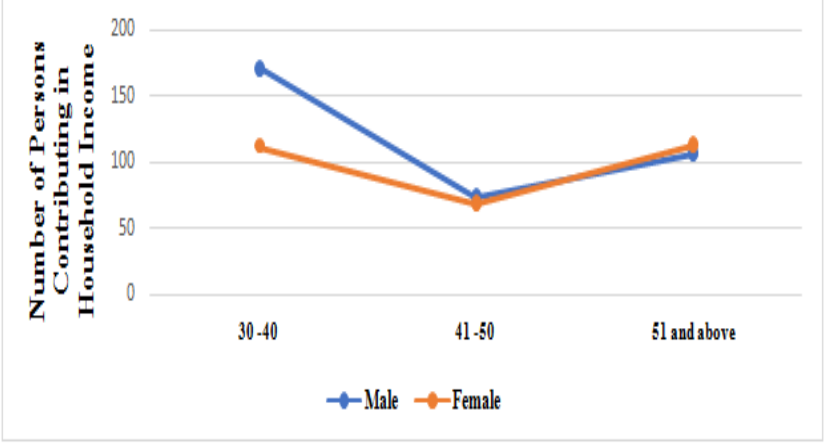

Fig.8: Contributory Matrix of Fiji

While making a comparison, one may identify that female contribution in household income is much higher in the Indo-Fijian community, than in the Indian. However, this finding is limited because the participants from India are specifically from Northern and Eastern areas like Uttar Pradesh and Bihar states, which are traditionally maledominant states. However, in the past few decades, India has experienced a dramatic change in attitude and women have become more career-oriented, particularly in cities. The proportionate contribution of women in household income may change if a survey were to be done in the rest of India, specifically the states where maternal society exists. The contribution made by the Indo-Fijian women in household income has not only achieved a better standard of life but also has contributed to the overall development of Fiji. 


\subsection{Role of Indo-Fijians in the Development of Business}

The economic progress of any nation is based on their physical and human resources. Being there liable human resource of the country, the descendants of Girmitiyas make immense efforts for the development of the nation. In the end, most of the indentured labourers decided to continue their journey in Fiji and contribute in their role as the shopkeepers, transport providers, hawkers, contractors, jewellers, involvement in the real estate business, etc., in the economic progress of Fiji. The Indo-Fijians have developed a leadership role to expand their businesses in all Pacific Island countries. A similar study conducted by O'Leonard (2010), stressed that a sign of developing business leadership can be seen in USA businesses and one-fourth of the total volume on its annual learning and expansion budget is spent on developing leadership. The investment in leadership development and training their people, in recent times, has appeared as one of the main purposes of the business policy of the company. To fill the needs of an evolving business environment and support their system effectively and efficiently, many business schools all over the world re-align their curriculum, mission and vision to include leadership development (Ghosh, 2015).Initially, in Fiji, most of the businesses were held by free migrant 'Gujrati', who took great risks to succeed with the majority of the labour force constituting descendants of Girmitiyas (Chand, 1997).

One of the cultural aspects developed by Indio-Fijians is to study the entrepreneurial skill in their lives. A study undertaken by Glancey et al.(1998), found that the dynamics of the entrepreneurship in a sample of small business service firms in the west of Scotland provide a deeper understanding of small firms and their society contribution by adopting a diverse perspective. In a similar study, conducted by Bryson (1996) and Kirby and JonesEvans (1997), it was established that entrepreneurship in the sample was handled by qualified specialists with administrative skills and motivation. The idea of motivation is to expand small businesses to achieve selfactualisation and economic remuneration. Today the descendants of Girmitiyas (indentured labourers) are involved in entrepreneurship of small, medium and big businesses like Northern Airways, Charan Jeet Singh Supermarkets, Shop-n-Save, Hanson's Supermarket, Nivis Motors, Sakura Cars, etc. This new structure provides new jobs for workers and is more focused on the entrepreneurial skills of the descendants for the growth of the economy (Gounder, 2016).

Traders from Fiji started to expand their exports to small islands which captured the attention of people for new commodities like building materials, food items, clothing, etc. Indo-Fijians, as well as the iTaukei population took an interest in this and Fiji started to enhance its name in business by importing things from New Zealand, Australia and Asian countries and selling them to different small island countries (Reserve Bank of Fiji, n.d.). This gives new direction for a domestic manufacturer which adds a vigorous connotation to investment. Indo-Fijians have not only helped in the progress of Fiji, but they have also added value to the progress of the Pacific Islands as a whole (COP23 Fiji, n.d.).

\subsection{Growth of Economy and Standard of Living}

Growth of the Fijian economy has been continuously increasing with the expansion of urbanisation, the advancement of technology and hardwork due to cultural changes. The rising economic level of Indo-Fijians has led the new generations taking more interest in achieving success in their lives. Fiji, being a small island with an overall population of less than one million, has also gone through four coups (Singh, 2012). Although the country faced many ups and downs from 1987 to2006, there have been developments and growth in various sectors. Descendants have proved their ability to rise from being Girmitiyas to government positions such as that of $\mathrm{Mr}$ Mahendra Pal Chaudhary who was the first Indo-Fijian Prime Minister appointed on 19th May 1999. As per the 2007 census, 112,153 Indo-Fijians, like professors, doctors, nurses, engineers, architects, and others had left Fiji (Berdford, 1989). The Fiji Country Study, 2004 stated that:

The migration was encouraged by the stresses and uncertainties created by the coups d'état of 1987 and 2000 by indigenous Fijians against governments that had been elected predominantly by Indian voters. The emigration of Indians (Indo-Fijians) has added substantially to decrease their numbers in Fiji from $51 \%$ of the population in 1970 (the year British colonial rule ended) to $44 \%$ today (Norton, 2004). This shows the political instability in Fiji created fear and anxiety amongst the Indo-Fijians that led them to migrate to other countries in search of a better life.

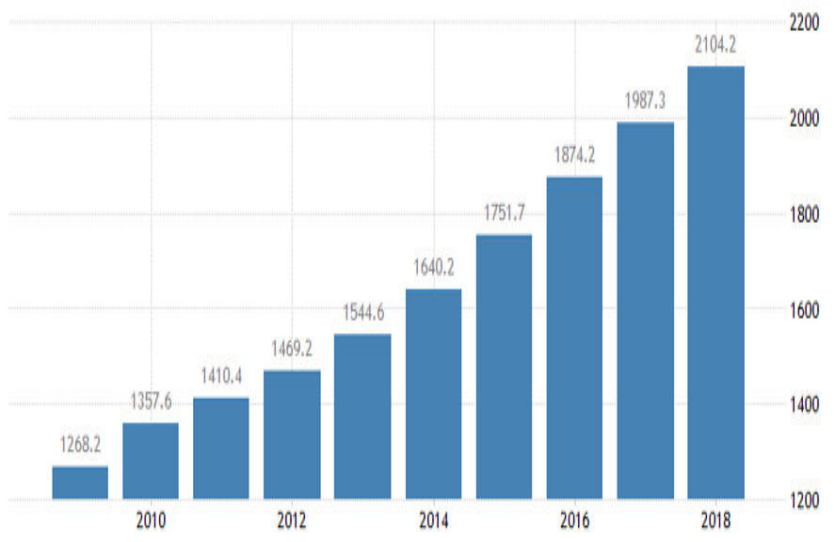

Fig. 9: GDP per Capita Income

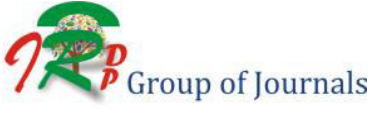




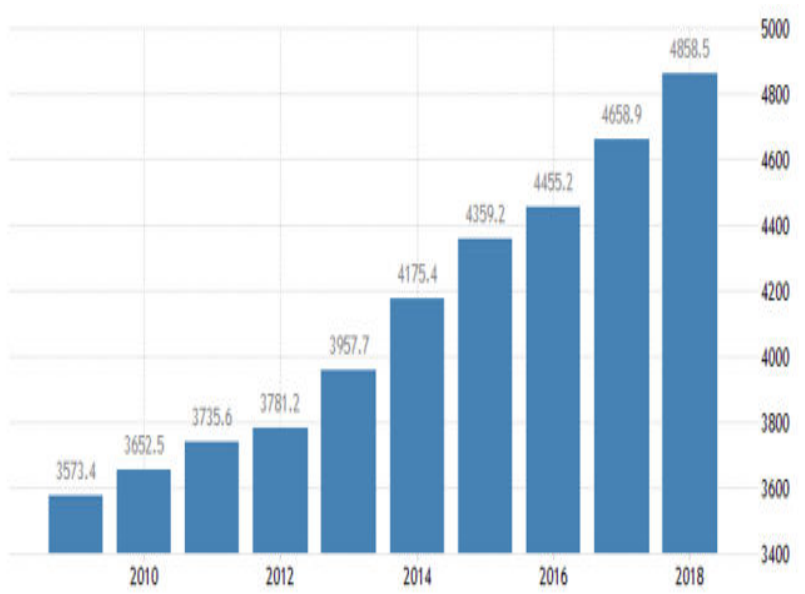

Fig.9(a): GDP Per Capita Income

The standard of living is measured by the GDP per capita income of the nation. Generally, it includes the welfare of families, the level of wealth and the substantial goods of a country.

The above figure indicates that, from 2009-2018, in every year the GDP per capita of Fiji was higher than that of India. By comparing the GDP per capitain these two countries, we can say, especially in 2014 and 2018, Fiji'sGDP per capita was higher by 2535.2 and 2754.3 US dollars respectively. It shows that the people of Fiji are earning more and that helps them to maintain their levels of wealth, and their lifestyle, and make economic progress for the betterment of their lives.

India is also growing, but the major factors that are keeping India on lower GDP levels are its growing population, a lower tax GDP ratio, unemployment, an unskilled labour force, and out-migration.

\section{Conclusions, Limitations, and Suggestions for Future Research}

This article has highlighted the cultural change and economic achievements of Indian indentured labourers in Fiji.The Indo-Fijians have risen from the ashes to build their futures against all the odds. These were the people who faced inhuman conditions and a ruthless administration during the colonial period, which at present one cannot imagine, but they stood up against all the atrocities and made progress. The uprising of Indo-Fijians has proved their potential, strength, commitment and integrity. Many of these indentured labourers remained in Fiji to payback their Karam Bhumi (workplace). For the growth of any society, the roles of men and women are equally essential. It was not only the men, but women also shouldered the responsibility for bringing prosperity in their lives. After conducting the empirical survey, we can conclude that, in contemporary society, women are allowed to work outside their homes. This has established their identity to play leadership roles in their family as well as in other aspects of life. One of the essential features found in this investigation is that the descendants have been liberated from the caste system and reservation policies in education and employment in Fiji; however, the reservation policies still prevail in India.

The study demonstrates that the practice of caste-based division of work and arranged marriage is not applicable in Fijian societies. With Fiji being a multiracial and multicultural country, inter-caste marriages are accepted, and parents are free from the burden of the dowry system. In India, arranged marriages and dowry systems are still dominant in society, and because of these prevailing traditions, there is reportedly, an increase in the number of dowry death sand many parents sacrifice their entire livelihood to pay dowry debts. As the dowry system has been seen as a social evil, the Government of India (in 1961) passed legislation known as the Dowry Prohibition Act, 1961 and made it very clear that the accepting and offering of dowries is an offence.

Today, descendants of Girmitiyas are teaching, training and nurturing lives in various countries. In particular, the Girmitiyas struggled for their survival, and they left a legacy to their descendants for a better standard of living. It can be observed that the facilities of government in various fields (like the availability of free education in secondary schools, free health care facilities, quality of life, the availability of employment, income and safety) have expanded for citizens. It is an achievement for the descendants of Girmitiyas that both husbands and wives are working on getting access to resources efficiently and comfortably which helps them to maintain their standard of living as in developed countries such as the UK, USA, and Australia, etc. The coup culture of Fiji has drawn an invisible line between the Indo-Fijian and iTauke communities. However, these two communities also have established a close companionship between them. It would be an ideal situation if both communities contributed and shared their thoughts for the progress of the nation. This cannot be achieved unless, and until, both the communities work hand in hand for development and communal harmony.

The findings of this research have both theoretical and managerial implications. The implications of this type of research include that the results will help to provide a deeper understanding of the descendants of Indo-Fijian's contribution to the overall economic achievements in their life. Although their grandparents and parents struggled during the Girmit time, the seeds they sowed made drastic changes in every aspect of their life. As briefly mentioned in section 4 (Methodology of the study), this study had

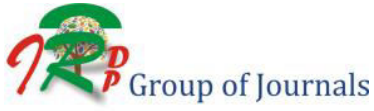


limitations, which included the fact that its findings were based on a limited sample size. India is a vast country both territorially and in population size. As indicated, researchers relied on the questionnaire and the data collected with 448 participants from Fiji and India especially from those provinces where their ancestors originated. The conclusion of the research is based on these collected data including the personal observations of the researchers (one of the researchers is Indo-Fijian and another has spent the last six years in Fiji). Because of these limitations, further research is recommended to cover a wider sample in order to gather information and to increase the general is ability of the findings.

\section{Reference}

[1] Albert, I. and Trommsdorff, G. (2014) 'The role of culture in social development over the life span: an interpersonal relations approach'. Online Readings in Psychology and Culture, Vol 6, No. 2 [online] https://scholarworks.gvsu.edu/cgi/viewcontent.cgi? article $=1057 \&$ context $=$ orpc (accessed 9 September 2019).

[2] An Overview of History of Indenture. [online] http://www.aapravasighat.org/English/Resources\%20Research/Doc uments/History\%20of\%20Indenture.pdf. (accessed 17January 2007).

[3] Ansari, M. (2018) 'Knowledge Is The Most Powerful Weapon' [online] 9 April 2018 https://medium.com/@mahekam_ansari/k nowledge-is-the-most-powerful-weapon-683fd387938f. (accessed 11 September 2019).

[4] Arya Samaj in Fiji. (n.d.) [online] https://en.wikipedia. org/wiki/ Arya_Samaj_in_Fiji. (accessed 17 September 2019).

[5] Bagde, K. S., Epple, D. and Taylor, L. (2016) 'Does Affirmative Action Work? Caste, Gender, College Quality, and Academic Success in India', American Economic Review, Vol.106 No. 6 , pp.1495-1521.

[6] Berdford, R. (1989) 'Out of Fiji...a perspective on migration after the coups', Pacific Viewpoint, Vol.30 No.2,pp.142-153.

[7] Bhagonandam, S.D. and Rao, D. S.(2015) 'A study on socio cultural factors influencing Indian Entrepreneurship: a critical examination',International Journal of Applied Engineering Research,Vol. 10, No. 23, pp.43807-43812.

[8] Bhagwati Saran Singh v. Parmeshwari Nandar Singh, (1944) ILR All 518.

[9] Bharadwaj, A. (2018) 'Indian culture evolves through time only to be caught in the regressive portrayal in cinema'. [online] 7 February. https:/qrius.com/indian-culture-evolves-time-caughtregressive-portrayal-cinema/. (accessed 12 July 2019).

[10] Biswas, C.S. (2016) 'Spousal violence against working women in India',Journal of Family Violence, Vol. 32 No. 1 [online] https:// search.proquest.com/ docview/ 1857261435/ fulltextPDF/ 515B27058C5345CCPQ/ 13?accountid=134156 (accessed 3 August 2018).

[11] Bryson, J.R. (1996) 'Small business service firms and the 1990s recession in the United Kingdom', Local Economy, Vol. 11, No. 3, pp.221-236.

[12] Cambridge Dictionary (2019) https://dictionary.cambridge. org/ dictionary/english/dowry (accessed 19 July 2019).

[13] CARLA. (2019) [online] http://carla.umn.edu/ culture/definitions. html (accessed 6 September 2019).

[14] Celep, A. Brenner, S.B. and Williams, R.M. (2016) 'Internal culture, external impact: how a changemaking culture positions foundations to achieve transformational change', The Foundation Review, Vol. 8 No. 1, pp.116-129.

[15] Chand, S. (1997) 'Ethnic conflict, income inequality and growth in independent Fiji',State, Society and Governance in Melanesia,
Discussion Paper[online] http://bellschool.anu.edu.au/sites/default/ files/publications/attachments /2015-12 /1997_06_chand\%5B1 \%5 D_0.pdf (accessed 16 July 2019).

[16] Chen, Y.S. (2017) 'Social networking practice of Viennese coffeehouse culture and intangible heritage tourism', Journal of Tourism and Cultural Change, Vol. 17, No. 2, pp.186-207.

[17] Chiang, F. (2005) 'A critical examination of Hofstede's thesis and its application to internationalreward management', International Journal Human Resource Management, Vol. 16, pp.1545-1563.

[18] Claros, A.L. andPerotti, V. (2014) 'Does culture matter for development?' Working Paper, World Bank Group. [online]http://documents.worldbank.org/curated/en/104741468325 132310/pdf/WPS7092.pdf. (accessed 18 August 2019).

[19] Collect, C. and Dalton, R. (2017) 'Cultural change in the Asian Pacific: introduction to the special issue on changing political cultures', Asian Journal of Comparative Politics, Vol. 2, No. 2, pp.109-111.

[20] Constitution of India.[online] https://www.india.gov.in/mygovernment/constitution-india(accessed 18 September 2019).

[21] COP23 Fiji UN Climate Change Conference Bonn (2018)https://cop23.com.fj/fiji-and-the-pacific/(accessed 19 December 2018).

[22] Dalmia, S. and Lawrence, G.P. (2005) 'Theinstitution of dowry in India: why it continues to prevail', The Journal of Developing Areas, Vol.38 No.2, pp.7-93.

[23] David, R.J., Sine, W.D. and Serra, C. K. (2017) Organizational Institutionalism, $2^{\text {nd }}$ ed., SAGE Publication,London.

[24] Deccan Herald. (2015) Rural areas see a middle-class rise, New Delhi, July 3, 2015, DHNS: 1:39 IST. https://www.deccanherald. com/content/487357/rural-areas-see-middle-class.html (accessed 29 January 2019).

[25] Delina, G. and Raya, R.P. (2016) 'Dilemma of work-life balance in dual-career couples - a studyfrom the Indian perspective', International Journal of Indian Culture and BusinessManagement, Vol. 12, No. 1, pp.1-27.

[26] Dimitrova, Y.(2019) 'Corporate culture change management', Economic Alternatives, No. 2, pp.296-312.

[27] Drishti (2019) Reservation in India, Last updated on July 24, 2019. https:/www.drishtiias.com /to-the-points/Paper2/ reservation-inindia (accessed 17 February 2019).

[28] Dwyer, S., Mesak, H. and Hsu, M. (2005) 'An exploratory examination of the influence of nationalculture on cross-national product diffusion', Journal of International Marketing, Vol. 13,pp.1-28.

[29] Eck, D.L. (2002) A New Religious America: How a "Christian Country" Has Become the World's Most Religiously Diverse Nation. Harper, SanFrancisco.

[30] Edlund, L. (2006) 'The price of marriage: net vs. gross flows and the South Asian dowry debate',Journal of the European Economic Association, Vol.4 No.2, pp.542-551.

[31] Flanigan, S.F. (2000) [online] https://scholarblogs.emory.edu/ postcolonialstudies/2014/06/20/arranged-marriages matchmakersand-dowries-in-india/ (accessed 16 October 2019).

[32] Fraenkel, J. (2007) 'The Fiji coup of December 2006: who, what, where and why?', inFrom Election to Coup in Fiji: The 2006 campaign and its aftermath, ANU Press, Australia, pp.420-449.

[33] Ghimire, A. and Samuels, F. (2014) Change and continuity in social norms and practices around marriage and education in Nepal [online] Country report, Overseas Development Institute,London.https://www.odi.org/sites/odi.org.uk/files/odiassets/publications-opinion-files/9181.pdf. (accessed 16Oct. 2019).

[34] Ghosh, K. (2015) 'Teaching and developing leadership in business schools: a multilevel evaluative approach in Indian context', International. Journal Indian Culture and Business Management, Vol. 10, No. 2, pp.178-192.

[35] Gillion, K.L. (1958) A History of Indian Immigration and Settlement in Fiji. Unpublished PhD thesis, Australian National University, Australia.

[36] Ginsburgh, V.A. and Throsby, D. (2006) Handbook of the Economics of Art and Culture, $1^{\text {st }}$ ed., Uk 
[37] Girmit.Org (n.d.) [online] http://girmit.org/. (accessed 7 November 2018).

[38] Girmit.Org. (n.d.) [online] http://girmit.org/?page_id=926. (accessed 11 December 2018).

[39] Glancey, K., Greig, M. and Pettigrew, M. (1998) 'Entrepreneurial dynamics in small businessservice firm', International Journal of Entrepreneurial Behavior and Research, Vol. 4 No. 3,pp.249-268.

[40] Govt. of India, (2013-2014) National Commission for Backward Classes. [online] Annual report, Trikoot-1, Bhikaiji Cama Place, New Delhi. http://www.ncbc.nic.in/Writereaddata/AR\%202013-14 \%20- \%20Pandey635705829394221982.pdf.(accessed 28 January 2020)

[41] Gounder, N. (May 2016). The legacy of the girmitiya in Fiji.[online] https:// asiapacificreport.nz/ 2016 /05/ 19 /neelashgounder-the-legacy-of-the-girmitiya-in-fiji/. $\quad$ (accessed 13 December 2018).

[42] Graf, C.V. (2014) 'Twice migrants' relationship to their ancestral homeland: The case of Indo-Fijians and India', The Journal of Pacific Studies, Vol. 27, No.2, pp.177-203.

[43] OECD(2005). Local economic and employment development (LEED) Culture and Local Development [online] https://books.google.com.fj/books?id=rojVAgAAQBAJ\&pg=PA27 \&lpg=PA27\&d (accessed 15 January 2020).

[44] Groeschl, S. and Doherty, L. (2000) 'Conceptualising culture',Cross Cultural Management, Vol. 7, No. 4, pp. 12-17.

[45] Guiso, L., Paola S., and Luigi Z. (2006). 'Does culture affect economic outcomes?',Journal of Economic Perspectives, Vol.20, pp.23-48.

[46] Heitzman, J. (2012). India: A Country Study. US Library of Congress, USA.

[47] Herskovits, M.J. (1969) Cultural Anthropology, New Delhi, India: Oxford and IBH.

[48] Indra Sawhney v. Union of India, 1992, 1992 Supp 2 SCR 454. [online] https://www.india.gov.in/my-government / constitutionindia. (accessed 26 July 2019).

[49] International Labour Organization, ILOSTAT database estimate, (2019) [online] https://ilostat.ilo.org/resources/lfs-resources/ (accessed 28 January 2020)

[50] Johnson, J.P. and Lenartowicz, T. (1998) 'Culture, freedom and economic growth: do culturalvalues explain economic growth?', Journal of World Business, Vol. 33, pp.332-355.

[51] Kalman, B. (2009) India: The Culture, 3rd ed., Crabtree Publishing Company, Canada.

[52] Kaur, G. and Kaur, M. (2016) 'The study of components of culture: values, norms, material objects, language and culture change', International Journal of Science Technology and Management, Vol. 5 No. 12.

[53] Kelly, J. (1988). 'From Holi to Diwali in Fiji: an essay on ritual and history', Man New Series, Vol. 23 No. 1, pp.40-55.

[54] Khanna, M. and Karandikar, M. (2013) 'Impact of relational collectivism on impulse buying for others', The International Journal of Indian Culture and Business Management, Vol. 7 No. 4 , pp.589-604.

[55] Kirby, K. and Jones-Evans, T. (1997) 'Small technology-based professional consultancy services in the United Kingdom', The Service Industries Journal, Vol. 17, No.1, pp. 155-172.

[56] Kishwar, M. (1989) 'Continuing the dowry debate',Economic and Political Weekly, Vol. 24 No. 49 [online], http://www.jstor.org/stable/4395689(accessed 26 August 2019).

[57] Lal, B. (2000) Chalo Jahaji: A Journey through Indenture in Fiji, ANU E Press, Australia. https://press-files.anu.edu.au/ downloads/ press/p212781/pdf/book.pdf (accessed 9 November 2018).

[58] Lanati, M. and Venturini, A. (2018) 'Cultural change and the migration choice', IZA - Institute of Labor Economics, pp.1-42. [online] http://ftp.iza.org/dp11415.pdf. (accessed 19 January 2020).

[59] Lee, S.M. and Peterson, S.J. (2000) 'Culture, entrepreneurial orientation, and global competitiveness', Journal of World Business, Vol. 35, pp.401-416.

[60] Madhani, P.M. (2010) Resource Based View (RBV) of Competitive Advantage: An Overview, pp.3-22, Icfai University Press,
Hyderabad, India, 2009, SSRN [online] https://ssrn.com/abstract=1 578704. (accessed 23 January 2020).

[61] Madsen, S.R. (2015)'Why do we need more women leaders in higher education?' HERS Research Brief, No. 1. [online] http:/hersnet.org/wp-content/uploads/ 2015/07/HERS-ResearchBrief-No.-1-Susan-Madsen-.pdf. (accessed 23 January 2020)

[62] Martin, J. (2006) “"That's the way we do things around here": An overview of organizational culture', Electronic Journal of Academic and Special Librarianship, Vol.7 No.1[online] $\mathrm{http}: / /$ southernlibrarianship.icaap.org/content/v07n01/martin_m01. htm. (accessed 22 January 2020).

[63] Maxweber, (1930) The Protestant ethic and sprit of capitalism, Routledge Classics, London

[64] Meyerson, D. (2001) Tempered Radicals: How People Use Difference to Inspire Change at Work, Harvard Business School Press, Cambridge, MA.

[65] Michael, E.W.V. and Grossmann, I. (2017) 'Cultural change: the how and the why', Association of Psychological Science,pp.1-17 [online] https://doi.org/10.1177/1745691617699971(accessed 21 January 2020).

[66] Michael, W. (2014). Culture, politics, and development, Policy Research Working Paper 6939. The World Bank, Washington DC. [online]https://asiafoundation.org/resources/pdfs/womensempower mentindiabriefs.pdf. (accessed 13 June 2019).

[67] Micklin, M. (1966) 'The Hindu joint family: the norms and the numbers',Pacific Affairs, Vol. 39, Nos. 3-4 [online] https://www.academia.edu/998241/The_Hindu_joint_family_The_ norms_and_the_numbers (accessed 20 September 2019).

[68] Ministry of Personnel, P.G. \& Pensions Department of Personnel \& Training, Government of India. (2010) Office memorandum [online]http://documents.doptcirculars.nic.in/D2/D02adm/36011_6 2010-Estt.(Res).pdf(accessed 21 January 2020).

[69] Misir, P. (2016) Speech on Girmitiyas [online] https: // www.unifiji.ac.fj / wp-content/uploads / 2018/02 / fiji-girmitiyasrevised-1.pdf (accessed 21 January 2020).

[70] Moag, R.F. (1978) 'Vernacular education in Fiji', South Pacific Journal of Teacher Education, Vol. 6 No. 2 [online] DOI:10.1080/03112137800602051978. (accessed 23 September 2019).

[71] Mohanty, M. (2017) 'Fiji kava: production, trade, role and challenges', The Journal of Pacific Studies, Vol.37 No.1, pp.5-30.

[72] Munday, A. (2018) '5 Practices to create a culture of innovation' Corporate Elearning [online] 28 May, https:// elearningindustry.com/ create-a-culture-of-innovation-5-practices. (accessed 20 September 2011).

[73] Muthusami v. Muthusami, 33 Mad 342.Office of the Registrar General \& Census Commissioner, India. [online] http://censusindia.gov.in/Census_And_You/migrations.aspx

[74] Naidu, V.(2013). Fiji: the challenges and opportunities of diversity [online]1-44. Minority Rights Group International 54 Commercial Street, London, United Kingdom. https:// www. refworld.o $\mathrm{rg} / \mathrm{pdfid} / 525 \mathrm{fbfda} 4 . \mathrm{pdf}$.

[75] Naidu, V. (2017). 'From Indian coolies to Fijians: culture and identity changes among Indo- Fijians', Fijian Studies, Vol. 15 No. 1[online] http://fijianstudies.net/wp-content/uploads/2017/03/15-1Naidu.pdf. (Accessed 19 September 2018).

[76] Nayyar, D. (2011) 'Discrimination and justice: beyond affirmative action', Economic and Political Weekly, Vol. 46 No. 42 [online] https: // www.epw.in / journal / 2011 / 42 / special-articles / discrimination- and- justice- beyond- affirmative- action. html. (accessed 21 January 2020).

[77] NCBC. (2012-2013).National Commission for Backward Class, Annual Report.[online] Trikoot-I Bhikaiji Cama Place, New Delhi, India.http://www.ncbc.nic.in/Writereaddata/AR\%202012 13\%20Pandey635705824205955927.pdf.(accessed 21 Oct. 2019).

[78] Norton, R. (2004) Fiji Country Study,[online]. 15 January 2004 https://assets.publishing.service.gov.uk/media/57a08ca840f0b652d d00147c/InformalRemittanceFijiStudy.pdf.(accessed 19Dec.2019).

[79] O'Leonard, K. (2010) The Corporate Learning Facebook: Statistics, Benchmarks, and Analysis of the US Corporate Training 
Market, Bersin \& Associates, Oakland, CA.

[80] Office of the Registrar General \& Census Commissioner, India.(2001)

[online].http://censusindia.gov.in/Census_And_You/religion.aspx (accessed 3 November 2019).

[81] Ooi, C.S. (2007) 'Un-packing packaged cultures: Chinese-ness in international business', EastAsia, Vol. 24, pp.111-128.

[82] Palriwala, R. (1989) 'Reaffirming the anti-dowry struggle',Economic and Political Weekly, Vol. 24 No. 17, [online] https://www.jstor.org/stable/pdf/4394737.pdf?refreqid=excelsior\% 3A3b25e11587ff76509ee36cffc94f9deb(accessed 23 September 2019).

[83] Pandey, N. and Srivastava, V. (2013) 'Factors affecting tourists' intention to purchase: a study of Indian domestic tourists', International. Journal of Indian Culture and Business Management, Vol. 6 No. 3, pp.314-329.

[84] Pathak, A.A. and Pandey, S. (2013) 'European vs. Indian ITES employees: a comparison of their work attitude and behavior', International Journal of Indian Culture and Business, Management, Vol. 6No. 2, pp.248-325.

[85] Pearsonhighered.com. (n.d.). 'Culture and culture change', [online]. https://www.pearsonhighered.com/assets/samplechapter/ 0/2/0/5/0205711200.pdf. (accessed 13 October 2019).

[86] Prakasa, R. (1982) Marriage, the family and women in India. Printox, South Asia Books.

[87] Qu, C. Dallen J. T. and Zhang, C. (2019) 'Does tourism erode or prosper culture? Evidence from the Tibetan ethnic area of Sichuan Province, China', Journal of Tourism and Cultural Change, Vol.17, No.4, pp. 526-543, DOI: 10.1080/14766825.2019.1600867.1

[88] Rai, S. (2016) 'The struggles, aspirations, achievements and legacy of the Girmityas',The Indian Diaspora [online] http:// girmit.org/?page_id=869(accessed 13 October 2019).

[89] Indra Sawhney Etc. Vs Union of India and OthersAIR 1993 SC 477.

[90] Refugee Review Tribunal Australia. (2009). [online] https://www.refworld.org/pdfid/4f1419b82.pdf. (accessed 7 April 2019).

[91] Reserve Bank of Fiji. (n.d.). 'Fiji and international trade' [online] https://www.rbf.gov.fj/getattachment/4eae6402-4241-4194-96864493173a98f9/Fiji-and-International-Trade-25-July,-Fiji-Times. (accessed 17 February 2019).

[92] Rosen, S. J. (2019) 'The Reincarnation(s) of Jaya and Vijaya: A Journey through the Yugas Reprinted from: Religions', in Jeffery D. Long, (Eds.), Perspectives on ReincarnationHindu, Christian, and Scientific pp.122-128. MDPI, Switzerland.

[93] Rössel, J. and Otte, G. (2010) 'Culture',in German Data Forum (RatSWD) (Ed.). Building on Progress, Verlag Barbara Budrich, Budrich UniPress,pp.1153-1172.

[94] Shodhganga.inflibnet. (n.d.) [online] https://shodhganga.inflibnet. ac.in/ bitstream/10603/97349/9/09_chapter\%204.pdf. (accessed 9 May 2019).

[95] Singh, D.P. (2010) 'Indian cultural values and ethos explained for the decision makers', International Journalof IndianCulture and Business Management, Vol. 3 No. 5, pp.592-606.
[96] Singh, K. (2007) 'The limited relevance of culture to strategy', Asia Pacific Journal ofManagement, Vol. 24, pp.421-428.

[97] Singh, N. and Krishnan, V.R. (2007) 'Transformational leadership in India: developing andvalidating a new scale using grounded theory approach', International Journalof Cross Cultural Management, Vol. 7, pp.219-236.

[98] Singh, R. T. (2012) 'Fiji's coup culture 1987-2006: A media perspective',Pacific Journalism Review, Vol. 18 No.2,pp.167-181.

[99] Sonawat, R. (2001) 'Understandingfamilies in India: areflection of societal changes', Mai-Ago, Vol.17 No.2, pp.177-186.

[100] Sondhi, N. and Chawla, D. (2014) 'A cluster analysis approach to grouping Indian womenprofessionals', International Journal of Indian Culture and Business Management, Vol. 8No. 1, pp.35-53.

[101] Sotomayor, S.,Claudia Gil Arroyo, C. G., and Carla Barbieri, C. (2019) 'Tradition and modernity side-by-side: experiential tourism among Quechua communities,'Journal of Tourism and Cultural Change, Vol17, No4, pp.449-466.

[102] Statistics Times. (2019) [online] http://statisticstimes.com/demographics/population-of-indianstates.php. (accessed 11 October 2018).

[103] Striking women org. (n.d.) [online] https://www.strikingwomen.org/module/map-major-south-asian-migrationflows/indentured-labour-south-asia-1834-1917. (accessed 3 October 2018).

[104] Suraj Bunsi Koer v. Sheo Prasad (1880) ILR 5 Cal 148.

[105] Sushil Kumar Sharma v. Union of India and others JT 2005(6), 266.

[106] The National Archives. (n.d.). [online] https:// www.nationalarchives.gov.uk/pathways/blackhistory/india/forced. htm. (accessed on 12 October 2019).

[107] The World Bank, IBRD.IDA. (2019) International Labour Organization, ILOSTAT database estimate [online] http://datatopics.worldbank.org/gender/country/fiji. (accessed 1 March 2019).

[108] Trnka, S. (2008). State of Suffering: Political Violence and Community Survival in Fiji, Cornell University Press, United States.

[109] UNESDOC Digital Library (2010). The power of culture for development, [online] http://www.lacult.unesco.org/lacult_en/docc/ The Power_of_Culture Development.pdf (accessed 22 July 2019).

[110] Zakia, A. et al (2016) 'Islam in Fiji: continuity, adaptation and change during the indenture and post-indenture periods', in Indentured Muslims in the Diaspora; Identity and Belonging of Minority Groups in Plural Societies, Manohar, New Delhi, pp. $275-300$

[111] Zhang, R.and Weng, L. (2017) 'Not all cultural values are created equal: cultural change in China reexamined through Google books', International Journal of Psychology[online] https://doi.org/10.1002/ijop.12436(accessed 21 January 2020). 